Beata Karwalska

(Archiwum Państwowe w Poznaniu)

\title{
Archiwa rodzinne w archiwach państwowych i konkurs dla archiwistów rodzinnych w Archiwum Państwowym w Poznaniu
}

W 2013 r. Naczelny Dyrektor Archiwów Państwowych, prof. Władysław Stępniak, zapoczątkował kampanię społeczną dotyczącą archiwów rodzinnych. Inauguracją była konferencja pt. Archiwa i kolekcje prywatne - dziedzictwo archiwalne, dziedzictwo kultury, którą zorganizował w marcu 2013 r. wspomniany powyżej Naczelny Dyrektor Archiwów Państwowych wspólnie z dr Hanną Krajewską, dyrektorem Archiwum Polskiej Akademii Nauk w Warszawie. Podczas konferencji omawiane były sprawy gromadzenia, ewidencjonowania, opracowywania i udostępniania archiwów prywatnych, czyli tzw. niepaństwowego nieewidencjonowanego zasobu archiwalnego, oraz kwestie współpracy między prywatnymi kolekcjonerami a instytucjami gromadzącymi i zabezpieczającymi tego rodzaju zbiory ${ }^{1}$. Naczelny Dyrektor Archiwów Państwowych, prof. Władysław Stępniak, otwierając konferencję, wypowiedział znamienne słowa na temat archiwów rodzinnych: „Mobilizuję archiwistów, by pozyskiwali do idei gromadzenia dokumentów rodzinnych wszystkich tych, którym bliska jest nie tylko własna tradycja rodzinna, ale i historia kraju. Bo przecież dzieje Polski składają się z milionowych jednostkowych przypadków postępowania osób, z których każda w mniejszym lub większym stopniu miała lub ma wpływ na bieg spraw publicznych. W momencie, gdy opłakujemy śmierć naszych dziadków lub babć warto zastanowić się nad tym, jakie dokumenty np. listy lub zdjęcia oni pieczołowicie chronili. I warto przekazać to wnukom i przyszłym pokoleniom"2 2 .

${ }^{1}$ http:/ / dzieje.pl/aktualnosci/szef-archiwow-w-polsce-tworzmy-archiwa-rodzinne (dostęp: 30 marca 2016 r.).

2 Tamże. 
Następną formą spopularyzowania idei: nie tylko państwo tworzy historię, było zorganizowanie konkursu pt. Zostan rodzinnym archiwista! przez Naczelną Dyrekcję Archiwów Państwowych wspólnie z Programem 1 Polskiego Radia ${ }^{3}$. Od 8 czerwca do 31 sierpnia 2013 r. na antenie Jedynki pojawiali się pracownicy archiwów państwowych: archiwiści oraz konserwatorzy, którzy zachęcali słuchaczy do tworzenia archiwów rodzinnych ${ }^{4}$. Przy okazji zachęcali do przysyłania na adres Radia informacji o własnych archiwach prywatnych. Na apel archiwistów i dziennikarzy odpowiedziało prawie sto osób. Rozstrzygnięcie konkursu nastąpiło 14 września 2013 r. Nagrodzonych zostało pięcioro laureatów, a czterem uczestnikom przyznano wyróżnienia ${ }^{5}$. Wszyscy otrzymali nagrody książkowe oraz możliwość opowiedzenia o swoim archiwum rodzinnym na antenie Polskiego Radia. W każdą sobotę, od drugiej połowy września do końca października 2013 r., prezentowano w Jedynce rozmowę z laureatem, w której omawiał on historię swojej rodziny oraz zachowane po niej pamiątki ${ }^{6}$. Zwieńczeniem konkursu było wydanie przez Naczelną Dyrekcję Archiwów Państwowych albumowej publikacji pt. Archiwa rodzinne. Zostań rodzinnym archiwista, w której zaprezentowane zostały skany archiwaliów rodzinnych nagrodzonych i wyróżnionych laureatów. Na końcu książki wymienieni zostali także z imienia i nazwiska wszyscy uczestnicy akcji ${ }^{7}$.

\footnotetext{
${ }^{3}$ Strona internetowa Programu 1 Polskiego Radia z informacją o konkursie: http:/ / www. polskieradio.pl/7/169/Artykul/861912,Zostan-rodzinnym-archiwista (dostęp: 30 marca 2016 r.).

${ }^{4}$ Wszystkie audycje kampanii Zostań rodzinnym archiwista!: http://www.polskieradio.pl/ 7/2980 (dostęp: 5 kwietnia 2016 r.).

${ }^{5}$ Laureatami konkursu Zostań rodzinnym archiwista! zostali: Monika Agopsowicz i Władysław Deńca, Zbigniew Zimny, Anita Golańska, Maria Romanowska oraz Aldona Młynarczuk. Wyróżnienia otrzymali: Eugeniusz Bałamącka, Adam Trzciński, Krystyna Krzyżanowska i Justyna Trojanowska.

${ }^{6}$ Audycje laureatów:
}

Monika Agopsowicz i Władysław Deńca http://www.polskieradio.pl/7/129/Artykul/ 937488,Ratowac-siebie-a-zaraz-potem-archiwum-Poznaj-wartosc-rodzinnych-pamiatek (dostęp: 5 kwietnia 2016 r.);

Zbigniew Zimny http://www.polskieradio.pl/7/2980/Artykul/942934,Historia-kresowejrodziny-z-lat-19331948 (dostęp: 5 kwietnia 2016 r.);

Anita Golańska http://www.polskieradio.pl/7/15/Artykul/953957,Rodzinne-archiwumswiadectwo-epoki-z-Zoliborzem-w-tle (dostęp: 5 kwietnia 2016 r.);

Maria Romanowska http://www.polskieradio.pl/7/2980/Artykul/948414,Rodzinne-archi wum-dwa-wieki-kilka-pokolen-jeden-los (dostęp: 5 kwietnia 2016 r.);

Aldona Młynarczuk http://www.polskieradio.pl/7/2980/Artykul/959485,Honor-Kiedysrozumiano-to-slowo-inaczej (dostęp: 5 kwietnia 2016 r.).

${ }^{7}$ Publikacja Archiwa rodzinne. Zostań rodzinnym archiwista w postaci elektronicznej jest dostępna pod linkiem: https://www.archiwa.gov.pl/pl/583-archiwa-rodzinne (dostęp: 31 maja 2016 r.). 
Zapoczątkowana kampania społeczna doczekała się kontynuacji poprzez otwarcie w prawie wszystkich archiwach państwowych punktów konsultacyjnych pod wspólną nazwą: "Archiwa rodzinne"8.

Do zadań konsultantów zajmujących się archiwami rodzinnymi należy przede wszystkim udzielanie porad na temat tworzenia archiwum domowego oraz wskazywanie sposobów dbania o dokumenty. Konsultanci mogą również pośredniczyć w przejmowaniu archiwów rodzinnych do zasobów archiwów państwowych, jeśli właściciel danego archiwum prywatnego wykaże takie zainteresowanie. Mogą także doradzać w kwestii prowadzenia poszukiwań genealogicznych.

Podsumowując efekty akcji radiowej Jedynki i archiwów państwowych Zostań rodzinnym archiwistą!, prof. Stępniak powiedział: „Kiedyś marzyłem o tym, by odrodziła się w Polsce tradycja archiwów rodzinnych. Zdaje się, że doczekałem tej chwili. Idea tworzenia archiwów rodzinnych spotkała się z niezwykle życzliwym przyjęciem i zainteresowaniem. Wydaje nam się, że ośmieliliśmy ludzi do myślenia w sposób bardziej odważny o własnym znaczeniu i znaczeniu tego, co znajduje się w ich rękach" ${ }^{\prime \prime}$.

Archiwa rodzinne nie są zjawiskiem nowym. W archiwach państwowych przechowywane są tzw. akta podworskie dotyczące rodów szlacheckich oraz spuścizny znamienitych członków poszczególnych rodzin. Według archiwistycznych przepisów metodycznych ${ }^{10}$, archiwa podworskie tworzą dokumenty powstałe $\mathrm{w}$ wyniku działalności osób, rodzin i rodów pozostających do 1945 r. właścicielami dóbr ziemskich. Archiwa te mogły zawierać przede wszystkim materiały archiwalne dotyczące posiadania i zarządzania majątkiem, pełnienia i wykonywania funkcji publicznych, ale również traktujące o sprawach osobistych i rodzinnych. Aby ułatwić przyszłym badaczom korzystanie z akt podworskich, twórcy wspomnianych przepisów, opracowali ramowy schemat systematyzacji zgromadzonych dokumentów ${ }^{11}$. W układzie akt, składającym się z sześciu grup rzeczowych, pierwsze znalazły miejsce ogólne materiały archiwalne dotyczące twórców zespołu (rodziny) i ich archiwum, dalej dokumenty poszczególnych członków rodu oraz ich korespondencja. Dopiero po dokumentach prywatnych ulokowano archiwalia dotyczące posiadłości, prawne oraz gospodarcze. Następnie umieszczono materiały in-

${ }^{8}$ Wykaz punktów konsultacyjnych wraz z danymi teleadresowymi: https:/ / www.archiwa.gov.pl/pl/586-punkty-konsultacyjne-archiwa-rodzinne (dostęp: 31 maja 2016 r.).

${ }^{9}$ http:/ / www.polskieradio.pl/7/2980/Artykul/964664,Akcja-Zostan-rodzinnymarchiwista-ozywila-dawna-tradycje (dostęp: 5 kwietnia 2016 r.).

10 Pismo okólne Nr 1 Naczelnego Dyrektora Archiwów Państwowych z 14 czerwca 1983 r. w sprawie wprowadzenia wskazówek metodycznych do opracowania archiwów podworskich w: Zbiór przepisów archiwalnych wydanych przez Naczelnego Dyrektora Archiwów Państwowych w latach 1952-2000, Warszawa 2001, s. 487-502.

11 Tamże, s. 496. 
nych osób i rodów oraz miejscowości, czyli dotyczące dalszej rodziny, a także znajomych, na samym końcu zaś utworzono grupę pod nazwą: różne, dla $n p$. wszelkiego rodzaju materiałów informacyjnych.

A jakie materiały archiwalne zostały wymienione w przepisach jako podstawa źródłowa archiwów rodzinnych i informacji biograficznych o poszczególnych członkach rodów? Wymieniając po kolei, były to: akta stanu cywilnego, utwory i prace naukowe, pamiętniki, sztambuchy, zapiski, papiery dotyczące udziału $\mathrm{w}$ życiu towarzyskim, dane o stanie zdrowia, materiały ikonograficzne itp., a także materiały związane z działalnością publiczną i pełnieniem różnych funkcji ${ }^{12}$.

Drugim, wspomnianym powyżej, zgromadzonym w archiwach państwowych rodzajem archiwum rodzinnego są spuścizny. Definicja spuścizny, wynikająca z przepisów metodyczny $\mathrm{ch}^{13}$, stanowi, że składają się na nią materiały archiwalne wytworzone $\mathrm{w}$ toku i w związku z życiem i działalnością osoby fizycznej, które ukazują główne kierunki jej życia, pracy i zainteresowań ${ }^{14}$. Również w tym przypadku został przygotowany schemat układu materiałów archiwalnych, podzielony na osiem głównych grup rzeczowych. Na pierwszym miejscu pojawiły się prace twórcy spuścizny, następnie dokumenty dotyczące jego działalności, a trzecie w kolejności - archiwalia biograficzne. Dalej usytuowano korespondencję wychodzącą i wpływającą oraz informacje o twórcy spuścizny opracowane przez inne osoby, m.in.: wspomnienia, recenzje prac, polemiki. W dalszej części znalazły się materiały archiwalne rodzinne, a po nich obcych osób. Na końcu utworzono grupę na wszelkiego rodzaju załączniki.

Najciekawszą grupą jest seria dotycząca materiałów archiwalnych biograficznych, ponieważ zawiera podgrupy, w których wymienione są szczegółowo rodzaje dokumentów wartych zarchiwizowania i pozostawienia w spuściźnie. Są to: autobiografie, ankiety personalne, zestawienia bibliografii prac własnych; dokumenty osobiste; dokumenty dotyczące przebiegu nauki szkolnej, studiów, pracy i działalności; zeszyty szkolne i notatki ze studiów; pamiętniki, dzienniki i albumy pamiątkowe; dyplomy honorowe, legitymacje odznaczeń, gratulacje i laurki; materiały gospodarcze i majątkowe; materiały dotyczące stanu zdrowia; świadectwa zgonu, klepsydry, nekrologi, kondolencje ${ }^{15}$.

Jak z powyższego przeglądu archiwistycznych przepisów metodycznych wynika, idea tworzenia archiwów rodzinnych istniała zawsze, jednakże

12 Tamże, s. 496.

13 Wytyczne Archiwum Polskiej Akademii Nauk z 1990 r. opracowania spuścizn archiwalnych po uczonych w: Zbiór przepisów archiwalnych wydanych przez Naczelnego Dyrektora Archiwów Państwowych w latach 1952-2000, s. 732-744.

${ }^{14}$ Tamże, s. 732.

15 Tamże, s. 733. 
trudniej było z jej realizacją. I to podejście aktualnie archiwa państwowe chcą zmienić. Obrazuje to zdanie Naczelnego Dyrektora Archiwów Państwowych prof. Stępniaka: „W Polsce warto wrócić do tradycji zbieractwa rodzinnego i nie wstydzić się tego, że tworzymy własne archiwa rodzinne. Niech to będzie obowiązek każdego seniora każdego rodu"16. Zgadzając się z powyższym, można jednak dodać, że nie tylko seniorzy, ale każdy, powinien dbać o własne dokumenty i gromadzić je w archiwum domowym. Dodatkowo wymienione przepisy, po zaktualizowaniu i dostosowaniu do rozwiązań i wymogów współczesności, mogą posłużyć jako podstawa do opracowania schematu tworzenia archiwum rodzinnego i wskazówek dla archiwistów rodzinnych.

Dotychczasowa praktyka stosowana w niektórych archiwach państwowych wykluczyła z wieczystego przechowywania archiwa prywatne rodzin mieszczańskich i chłopskich lub osób, które nie wykazały się dość wyjątkową działalnością. Stan zachowania archiwów rodzin i osób jest zapewne niezadowalający, co może skutkować również niewystarczającym materiałem badawczym dla naukowców zajmujących się szeroko rozumianą historią społeczną. Należy mieć nadzieję, że kampania społeczna uzmysłowi konieczność gromadzenia dokumentów rodzinnych każdemu, ale również archiwistom państwowym. Bez wątpienia dokumenty rodzinne stanowią uzupełnienie materiałów archiwalnych wytwarzanych przez różnego rodzaju jednostki organizacyjne pozostające pod nadzorem archiwów państwowych i ukazują, jak polityka państw wpływa na historię poszczególnych osób i ich rodzin.

Jak ważne jest archiwum rodzinne, przekonać się można w sytuacjach, kiedy brakuje dokumentów niezbędnych do załatwienia określonej sprawy. Nie zawsze też można liczyć na uzyskanie kopii z instytucji, które wytworzyły i wydały wcześniej interesujące "papiery”. Z tej przyczyny rozsądnym posunięciem jest pieczołowite gromadzenie i przechowywanie akt, ponieważ nie wiadomo, kiedy i w jakim momencie będą mogły się przydać.

A z drugiej strony, warto też zadbać o kolekcjonowanie wszelkiego rodzaju pamiątek i dokumentów po najbliższych, żeby archiwum rodzinne "przemówiło" o życiu i działalności przeszłych pokoleń,

Idąc wzorem prof. Władysława Stępniaka, Archiwum Państwowe w Poznaniu w 2015 r. zorganizowało konkurs dla archiwistów rodzinnych pt. Najstarszy dokument w mojej rodzinie. Głównymi celami konkursu były: promowanie i popularyzowanie archiwów rodzinnych, zachęcanie do tworzenia archiwów prywatnych oraz ukazanie archiwów rodzinnych jako miejsca

16 http:/ / dzieje.pl/aktualnosci/szef-archiwow-w-polsce-tworzmy-archiwa-rodzinne (dostęp: 30 marca 2016 r.). 
przechowywania źródeł do historii regionalnej uzupełniającej zasób archiwów państwowych.

Na konkurs odpowiedziało szesnastu archiwistów rodzinnych ${ }^{17}$. Aż pięciu z nich przysłało skany fotografii. Najstarsze zdjęcia pochodziły z lat siedemdziesiątych i dziewięćdziesiątych XIX w., młodsze z lat 1917-1918 i 1936-1937, a najmłodsze z lat II wojny światowej i roku 1946. Większość przedstawiała członków rodziny i przodków w fotografiach pozowanych, wykonanych $\mathrm{w}$ zakładach fotograficznych, ale i w plenerach czy podczas uroczystościach rodzinnych. W jednym tylko przypadku temat nadesłanych zdjęć wyszedł poza schemat, ponieważ związany był z działalnością krewnego. Mianowicie, ojciec archiwisty rodzinnego, będąc harcerzem i fotografem amatorem, uwiecznił paradę Związku Harcerstwa Polskiego na ulicach Poznania, a dokładnie przed Zamkiem Cesarskim, oraz uroczystą zbiórkę harcerzy na placu Wielkopolskim. Zdjęcia te zostały również przez niego opisane odnośnie do daty, miejsca i zdarzenia, co świadczy o niezwykłej intuicji historyczno-archiwistycznej tego wówczas młodego człowieka.

Poza materiałami ikonograficznymi na konkurs przysłano także skany zachowanych i przechowywanych w domach książek. Jedna z nich to Żywot świętego Jana Chryzostoma, wydana w Poznaniu w 1854 r. W publikacji, na wewnętrznej stronie okładki, wymieniono sześć pokoleń właścicieli, urodzonych między rokiem 1842 a rokiem 1988. Druga zaś nosi tytuł Kobieta lekarka domowa i pochodzi z 1908 r. Jak wynika z nadesłanego przez archiwistę rodzinnego opisu, opracowanie to służyło jego prababci przy sprawowaniu opieki nad chorymi. Wraz z kopią książki przysłany został również skan obrazka religijnego z 1911 r. przedstawiający cudowny obraz Matki Boskiej ze Starejwsi, podarowany prababce przez pacjenta w podzięce za opiekę.

Stosunkowo dużo dokumentów przysłanych na konkurs pochodzi z XIX w. Wśród nich są: odpis wyroku sądu gminnego w Olewsku, obecnie miasta na Ukrainie, z 1882 r.; zaświadczenia z lat 1885, 1886 i 1897 o złożeniu przysięgi na poddaństwo Rosji przez mieszkańców Prus, pochodzących z Wielkopolski, czyli terenu zaboru pruskiego, osiadłych na ziemiach zostających pod zaborem rosyjskim; akt notarialny z 1893 r. Również z tego okresu pochodzą dokumenty żołnierskie - książeczka wojskowa wydana w $1896 \mathrm{r}$. oraz poświadczenie odbycia służby wojskowej z $1898 \mathrm{r}$. Dołączony do nich został skan odpisu metryki z 1922 r. dotyczący aktu urodzenia z 1876 r. osoby, do której należały wyżej wymienione dokumenty służby wojskowej. Inny

17 Nazwiska uczestników w kolejności alfabetycznej: Aneta Andrzejewska, Justyna Bauza, Andrzej Budzyński, Marcin Chojnacki, Magdalena Czub, Jan Czyżewski, Ilona Gołaska, Małgorzata Hoffmann, Ziemowit Jurczyński, Anna Kierzynka, Kuba Kruszyk, Michał Kwaśniewski, Rafał Rissmann, Grzegorz Szymajda, Łukasz Staśkiewicz, Bogdan Winowski. 
archiwista rodzinny nadesłał skan odpisu aktu urodzenia z 1865 r., wystawionego w $1929 \mathrm{r}$.

Z okresu I wojny światowej natomiast pochodzi kopia listu autorstwa 24-letniego żołnierza, napisanego 20 października 1915 r. do rodziny z frontu. Archiwista rodzinny dołączył do listu fotografię młodego człowieka oraz odpis aktu zgonu z 14 stycznia 1916 r., z którego wiadomo, że zginął 26 października 1915 r., czyli prawie tydzień po napisaniu listu. Inną pamiątką po krewnym, przesłaną na konkurs, związaną z I wojną światową, był skan kilku stron pamiętnika opisującego okres od 6 sierpnia 1914 r. do 13 października 1916 r., walki na frontach zachodnich, w Belgii, Holandii, Francji, pobyt w lazarecie w Spandau oraz walki na froncie wschodnim. Do tego dołączone zostały skany fotografii przedstawiające autora wspomnień. Z dwudziestolecia międzywojennego, a dokładniej z 1930 r., Archiwum otrzymało skan życzeń sporządzonych z okazji 25. rocznicy ślubu. Z okresu okupacji hitlerowskiej, poza wspomnianymi powyżej fotografiami, dostarczono też skan Arbeitsbuch oraz dyplom błogosławieństwa dla rodziny od papieża Piusa XII. Oba dokumenty pochodzą z $1942 \mathrm{r}$.

Jedna osoba spośród archiwistów rodzinnych przysłała na konkurs bardzo oryginalną pamiątkę. Mianowicie pochodzącą z drugiej połowy lat sześćdziesiątych XX w. kartkę z kalendarza. W informacji opisującej przesyłkę nadawczyni zaznaczyła, że nie jest to najstarszy dokument, ale największy skarb w archiwum domowym, ponieważ świadczy o miłości jej rodziców. Jej mama skrupulatnie przechowywała tę kartkę przez prawie pół wieku, a dotyczyła ona dnia, w którym archiwistka się urodziła. Dopisane na niej zostały: imię, waga, wzrost oraz godzina przyjścia na świat dziecka.

Wszystkie prace konkursowe wraz z załączonymi skanami dokumentów i fotografii były niezwykle interesująco przygotowane i opisane. Większość zawierała bardzo dużo informacji, niektóre mniej. Ale wszystkie niosły ze sobą niezwykły ładunek emocjonalny. Emanowało z nich wzruszenie, radość i duma $z$ powodu ich posiadania $w$ archiwach domowych. Jedna z prac wyróżniła się spośród szesnastu nadesłanych. Kobieta przedsiębiorcza - Katarzyna Gummert w świetle aktu notarialnego z 1893 roku Michała Kwaśniewskiego była właściwie artykułem, który od razu nadawał się do publikacji. Autor w niezmiernie ciekawy sposób opisał życie swojej przodkini i podejmowane przez nią decyzje, ujmując to w szerokim kontekście genealogicznym. Temat życia kobiety pochodzącej ze stanu chłopskiego nie jest powszechny, tym bardziej warto przeczytać niniejszą pracę. 
Beata Karwalska

\title{
Archiwa rodzinne w archiwach państwowych i konkurs dla archiwistów rodzinnych w Archiwum Państwowym w Poznaniu
}

\begin{abstract}
Streszczenie
Tekst przedstawia informacje o zainicjowaniu kampanii społecznej na temat archiwów rodzinnych i utworzeniu punktów konsultacyjnych w archiwach państwowych. Jest próbą zwrócenia uwagi na kwestie gromadzenia dokumentów w archiwach prywatnych. Omawia również konkurs dla archiwistów rodzinnych na temat: „Najstarszy dokument w mojej rodzinie” zorganizowany przez Archiwum Państwowe w Poznaniu z okazji Międzynarodowego Dnia Archiwów w 2015 r.
\end{abstract}

\section{Family archives in national archives and a competition for family archivists in the National Archive in Poznan}

\begin{abstract}
The text presents information about the introduction of a social campaign concerning family archives and about the creation of information points in national archives. Its aim is to draw attention to the issue of collecting documents in family archives. It also discusses the competition for family archivists on the following subject: "The oldest document in my family", organized by the National Archive in Poznań to celebrate the International Archives Day in 2015.
\end{abstract}

